\title{
ANALYSIS OF GOVERNMENT EXPENDITURE AND LABOR ON GROSS REGIONAL DOMESTIC PRODUCT IN MALUKU PROVINCE OF INDONESIA
}

\author{
Amin Mohamat ${ }^{*}$, Lecturer \\ College of Administrative Sciences Said Perintah Masohi, Central Maluku, Indonesia \\ *E-mail: mohamatamin727@gmail.com
}

\begin{abstract}
Gross Regional Domestic Product (GRDP) is an indicator used to measure economic growth at the regional level. This study aims to analyze the effect of government expenditure and labor on Gross Regional Domestic Product (GRDP) in Maluku Province. Data sources used are secondary data obtained from the Central Bureau of Statistics of the Province of Maluku in the form of government expenditure, labor and GRDP period 2010-2016. Data analysis uses multiple regression approaches. The findings in this study indicate that Government expenditure and labor simultaneously influence the Regional Gross Regional Domestic Product of Maluku Province, while the partial effect shows that government expenditure has an effect on Gross Regional Domestic Product and labor does not affect the Gross Regional Domestic Product of Maluku Province. This study recommends that achieving effective economic development; local government expenditures must be allocated appropriately in accordance with the potential of each region in Maluku Province.
\end{abstract}

\section{KEY WORDS}

Government expenditures, labor, GRDP, multiple regression.

Economic development is needed by a country in order to improve the standard of living and welfare of the community, by developing all fields of an activity that exists in a country. Economic development is very important because when talking about economic development means there is a development process that involves economic growth followed by several changes. In the development process, local governments have an important role because local governments are more aware of the potential and resources of both humans and nature that are owned by their own regions (Meier, 1995) in Alfiyanto (2014).

In the process of economic development, economic growth is one of the benchmarks of success in economic development. The increase in economic growth means that there is an increase in economic activity in the area, if there is a decline then economic activity in the area is experiencing a decline. Economic growth that occurs during a certain period is inseparable from the development of each sector or sub-sector that contributes to the economic added value of a region (Novianto and Atmanti, 2013). High economic growth still leaves problems that must be faced in the development of a region (Dhanang, 2013).

Economic the growth of a country can be seen from the production of goods and services that can be produced by the economy in the country. Myrdal stated that development as a movement upward from the whole social system. Because of that economic growth is not only the attention and agenda of the central government or nationally but also the attention and agenda of each region in a country. This is because a country's economic growth is also influenced by economic growth in each region. For this reason, regional economic growth is an important concern not only for the regional government but also for the central government. To find out the regional economic growth, it can be seen from the region's Gross Regional Domestic Product (GRDP) (Weley et al. 2015).

According to the Department of Economic and Monetary Statistics of Bank Indonesia, GRDP is one of the important indicators for knowing the economic conditions in an area within a certain period, both at current prices and on the basis of constant prices. Thus, the GRDP value is able to be used as a benchmark for the value of goods and services produced by a region in a certain period by using the production factors owned by the region. 
There are several reasons underlying the selection of economic growth using gross regional domestic product (GRDP) in Adriansyah (2017), namely:

- GRDP is the amount of added value produced by all production activities in the economy. This means that an increase in GRDP also reflects an increase in remuneration to the production factors used in the production activity.

- The area limit of GRDP calculation is the country (domestic economy).

- GRDP is one indicator that can be used as a measure to assess the success of a region's development, or reflected through GRDP growth.

The role of government is very important in improving economic growth because it includes providing public needs and services to the public that cannot be provided by the private sector. This role is contained in government expenditures, namely, the overall expenditure made, namely expenditures which include consumption and investment. Government expenditure is government expenditure (expenditure) on capital goods, consumer goods, and services (Anggraeny, 2016).

Government expenditure is an instrument to measure the magnitude of the role of the government and the role of the private sector. Besides that, government expenditure can be used as a determinant of the amount of aggregate expenditure as well as determining the growth of real GNP in the short term. Government expenditure on goods and services is grouped into two groups, namely government consumption and government investment (Umayi. 2017). Included in the first category (government consumption) is the purchase of goods and services that will be consumed, such as paying the salaries of school teachers, buying stationery and paper for use and buying gasoline for government vehicles. While government investment includes expenditure to build infrastructure such as roads, schools, hospitals, and irrigation (Sukirno, 2006) in Chandra (2012).

Workforce contributes greatly to economic growth. The population is one of the factors that influence economic growth in a region. The increase in population over time is able to become a driver and inhibitor of economic growth. The size of the population will cause a large amount of labor. The results of the study Fahri (2013) show that government expenditure in the industrial and labor sectors have a positive and significant effect on regional economic growth. Finally, the role of local governments through government expenditures that can stimulate employment is expected to increase regional economic activities in order to achieve economic growth and increase community income. From the description above, it is necessary to examine the effect of government expenditure and labor on GRDP in Maluku Province in 2010-2016.

\section{METHODS OF RESEARCH}

This the study uses quantitative data, the data sources used are secondary data obtained from the Central Bureau of Statistics of the Province of Maluku in the form of government expenditure and labor and GRDP in 2010-2016, where government expenditure is taken from direct expenditure, labor based on the workforce, whereas GRDP is based on the Constant Price Base. Data the analysis in this study uses multiple regression analysis USE SPSS 22 program. The multiple regression models in this study can be written:

$$
Y=\beta_{0}+\beta_{1} X_{1}+\beta_{2} X_{2}+e
$$

Where: $Y=$ GRDP; $X_{1}=$ Government Expenditure; $X_{2}=$ Labor; $E=$ Error; $\beta 0=$ Constanta; $\beta 1, \beta 2, \beta 3=$ Regression coefficient.

\section{RESULTS AND DISCUSSION}

This regression analysis is used to Statistic the amount of influence between independent variables, namely government expenditure $\left(X_{1}\right)$ and Labor $\left(X_{2}\right)$ on the dependent variable, namely Gross regional domestic product (GRDP) in Maluku province. Hypothesis testing is carried out simultaneously and partially. 
Simultaneous Hypothesis Test. To test the existence of a positive and significant influence between variables of government expenditure $\left(X_{1}\right)$ and Labor $\left(X_{2}\right)$ on the dependent variable, namely Gross regional domestic product (GRDP) in Maluku province. Simultaneously used the Test, hypothesis testing criteria as follows:

- $\mathrm{H}_{0}$ rejected if $\mathrm{F}$ Statistic $>\mathrm{F}$ table or significance value $<0.05$;

- $\mathrm{H}_{0}$ accepted if $\mathrm{F}$ Statistic $<\mathrm{F}$ table or significance value $>0.05$;

Simultaneous testing can be seen in Table 1.

Table 1 - Simultaneous Test ( $F$ test)

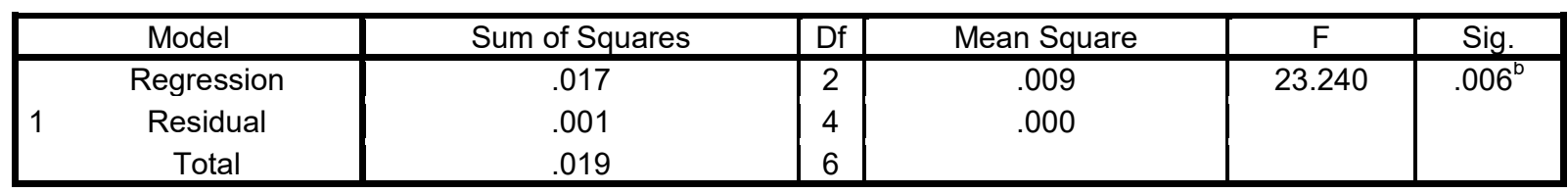

a. Dependent Variable: Gross Regional Domestic Product (GRDP).

b. Predictors: (Constant), Government Expenditure, Labor.

Source: Primary data processed, 2018.

In Table 1, it can be explained at a 95\% confidence level $(\alpha=0,05)$ and whereas $F_{\text {table }}$ amounted equal to $=4.32$ while the value of $F$ statistic $=23.240$, thus the value of $F$ statistic $>F$ table so that $\mathrm{H}_{0}$ rejected or $\mathrm{H}_{a}$ accepted, so it is statistically proven that there is a real influence of government expenditure $\left(\mathrm{X}_{1}\right)$ and Labor $\left(\mathrm{X}_{2}\right)$ simultaneously on Gross regional domestic product (GRDP) in Maluku province. Therefore the hypothesis which states that there is a positive and significant influence between government expenditure $\left(X_{1}\right)$ and Labor $\left(X_{2}\right)$ simultaneously on improving the Gross regional domestic product (GRDP) in Maluku province can be accepted and tested statistically.

Hypothesis Testing in Partial ( $t$ test). T test to determine whether the o government expenditure $\left(X_{1}\right)$ and Labor $\left(X_{2}\right)$ partially have a significant effect on GRDP in Maluku. If $T_{\text {Statistic }}>t$ table or $-T_{\text {Statistic }}<-T_{\text {table }}$ at a significance level of a 0.05 then $\mathrm{H}_{0}$ rejected and $\mathrm{H}_{1}$ accepted. Meanwhile if TStatistic $<t$ table or $-T_{\text {Statistic }}>-T$ table then $H_{0}$ accepted and $H_{1}$ rejected. The results of the t test can be shown in Table 2.

Table 2 - Partial Test (t Test)

Coefficients $^{a}$

\begin{tabular}{|c|c|c|c|c|c|}
\hline \multirow{2}{*}{ Model } & \multicolumn{2}{|c|}{ Unstandardized Coefficients } & Standardized Coefficients & \multirow{2}{*}{$\mathrm{t}$} & Sig. \\
\cline { 2 - 5 } & $\mathrm{B}$ & Std. Error & Beta & 2.513 & .066 \\
\hline \multirow{2}{*}{1 (Constant) } & 7.758 & 3.087 & & 4.594 & .010 \\
Government Expenditure & .476 & .104 & 1.159 & -1.003 & .373 \\
\hline
\end{tabular}

a. Dependent Variable: Gross Regional Domestic Product

Source: Primary data processed, 2018.

Based on Table 2, the regression equation is obtained as follows:

$$
\log (Y)=2.06+0.476 \log X_{1}-0.627 \log X_{2}+e
$$

Table 2, obtained the value of $\mathrm{T}_{\text {Statistic }}$ of the government expenditure variable equal to 4.59. whereas t table amounted to $2.78 \mathrm{As} \mathrm{T}_{\text {statistic }}>\mathrm{T}$ table namely $4.59>2.78$ or significance value $(0.00<0.05)$ then $\mathrm{H}_{0}$ rejected and $\mathrm{H}_{1}$ accepted so it can be concluded that partially the government expenditure influences the Gross Regional Domestic Product of Maluku Province.

Hypotheses testing for Labor variables in Table 2, obtained the value of $T_{\text {Statistic }}$ equal to -1.003 . Meanwhile $t$ table equal to -2.78 . As $T_{\text {Statistic }}<T_{\text {table }}$ namely $-1.003>-2.78$ or not significance value $(0.373>0.05)$ then $\mathrm{H}_{0}$ accepted and $\mathrm{H}_{1}$ rejected so that it can be concluded 
that partially the Labor did not influence the Gross Regional Domestic Product of Maluku Province.

Determination Coefficient $\left(R^{2}\right)$. To find out the magnitude of the contribution of the independent variable to the dependent variable used the $R^{2}$ value presented in Table 3:

Table 3 - Determination Coefficient

\begin{tabular}{|c|c|c|c|c|}
\hline Model & $\mathrm{R}$ & R Square & Adjusted R Square & Std. Error of the Estimate \\
\hline 1 & $.960^{\mathrm{a}}$ & .921 & .881 & .01915 \\
\hline
\end{tabular}

a. Predictors: (Constant), Government Expenditure, Labor.

Source: Primary data processed, 2018.

The determination coefficient is used to Statistic the influence or contribution of the independent variable to the dependent variable. In Table 3, Correlation coefficient 0.921, indicating that performance is influenced equal to $92.10 \%$ by Government Expenditure and Labor and the remaining $7.90 \%$ is influenced by other factors outside this research. These results concluded that the ability or great diversity of Government Expenditure and Labor in explaining the performance was $92.10 \%$.

\section{DISCUSSION OF RESULTS}

Effect of Government Expenditures on GRDP. The results of the analysis show that government expenditures has a positive and significant effect on GRDP in Maluku Province. This is in accordance with Anggraeny's (2016) study which states that government expenditures has a significant positive effect on GRDP in Surakarta City. This is because the support of government expenditures on development activities from year to year is increasing, in the concept of macroeconomic government expenditures will increase the national economy. According to Mangkoesoebroto (1998), in Sitaniapessy (2013) government expenditure reflects government policy. The research presented by Alfawwaz (2015), Ponzetto \& Troiano (2018), d'Agostino et al., (2018), Hein (2018), Nurudeen \& Usman (2010),. Fölster \& Henrekson (2001), Devarajan et al., (1996), Cashin (19995), and Fan et al., (2000), that total government expenditures has a positive impact on economic growth. If the government has established a policy to buy goods and services, government expenditure reflects the costs incurred by the government to implement the policy. Government expenditures in real terms can be used as an indicator of the amount of government activity financed by government expenditure. The bigger and more government activities, the greater the government expenditure involved. The proportion of government expenditure on national income (GNP) is a measure of government activity in an economy.

Supported by research Ratih's et al (2017) also states that government expenditures has a positive and significant effect on GRDP. GRDP can describe the ability of an area to manage its natural resources. The amount of GRDP produced by each region is very dependent on the potential of natural resources and the factors of production of the area. The limitations in the provision of these factors cause the GRDP to vary between regions. GRDP based on constant prices shows the overall economic growth rate / each sector of the economy from year to year and measures the rate of growth of consumption; investment and foreign trade, inter-island / inter-provincial trade (Sulaksono, 2015).

Government expenditure policies that can directly stimulate economic growth are expenditure because these variables are realized in economic and social infrastructure development. The development of government expenditure is measured by the amount of direct expenditure and indirect expenditure. This classification of direct and indirect expenditure is used in the central and regional government budgeting systems (Zahari, 2017). Another study put forward by Budiyanto et al., (2014) suggests that government expenditures can have an impact on GRDP.

Influence of Labor on GRDP. The results of the analysis show that the workforce does not affect the GRDP in Maluku Province. The results of this study are supported by research 
conducted by Ratih et al. (2017) which states that labor has a positive and insignificant effect on GRDP in the Sarbagita Region of Bali Province, this is due to a large number of unemployed in the area, so the region does not receive taxes. Supported by research Pamungkas, et al (2018) which states that labor does not have a positive effect on GRDP, this is because of that population growth (increasing labor) in the long run, will reduce the level of development to a lower level. This happens because the law of increasing yields decreases because, in the long run, the economy will reach a stationary state. With the low employment available, the resulting productivity also decreases. To be able to increase productivity, what is needed is an increase in capital accumulation. A large population but very high efficiency and productivity can increase the rate of economic growth.

Research by Wibowo et al., (2017) and Salim (2003) suggests different things where Labor has a positive and significant effect on Gross Regional Domestic Income (GRDP). This is because Labor is one of the factors of production that drives the economy in the region. Aside from being a productive workforce, labor is also a source of regional income from the tax sector and is also a consumer. In line with Maharani's research (2017) which states that labor has a significant effect on GRDP, this is because Labor is seen as a production factor that is able to increase the efficiency of other production factors (cultivating the land, utilizing capital etc.) so that the company views labor as an investment and many companies that provide education to their employees as a form of labor capitalization.

\section{REFERENCES}

1. Alfawwaz, Torki. 2015. The Impact of Government Expenditures on Economic Growth in Jordan (1980-2013). International Business Research. 9. 99. 10.5539/ibr.v9n1p99.

2. Alfiyanto, D. F. 2014. Analisis Pengaruh Jumlah Penduduk, Tenaga Kerja, Tingkat Pendidikan Dan Pengeluaran Pemerintah Terhadap Pertumbuhan Ekonomi Di Kabupaten Grobogan Tahun 1990-2012 (Doctoral dissertation, Universitas Muhammadiyah Surakarta)

3. Andriyansah, D. 2017. Pengaruh Investasi, Tenaga Kerja Dan Indeks Pembangunan Manusia Terhadap Pertumbuhan Ekonomi Kabupaten Dan Kota Di Jawa Barat Tahun 2011-2015 (Doctoral dissertation, Fakultas Ekonomi dan Bisnis Unpas Bandung).

4. Anggraeny, A. A. (2016). Analisis Pengaruh Pengeluaran Pemerintah, Jumlah Tenaga Kerja, dan Tingkat Pendidikan terhadap Pertumbuhan Ekonomi di Kota Surakarta Tahun 1991-2013 (Doctoral dissertation, Universitas Muhammadiyah Surakarta).

5. Barro, R. J. (1990). Government spending in a simple model of endogeneous growth. Journal of political economy, 98(5, Part 2), S103-S125.

6. Budiyanto, D. S., Sinaga, B. M., \& Sudaryanto, T. 2014. The Impacts of Regional Governments' Expenditures on the Agricultural Sector and Economic Performance in Indonesia. IOSR Journal of Economics and Finance (IOSR-JEF). 4(2), 33-40

7. Candra, E. W. 2012. Analisis Peranan Pengeluaran Pemerintah, Tenaga Kerja Dan Penanaman Modal Dalam Negeri (PMDN) Terhadap Pertumbuhan Ekonomi Provinsi Jawa Timur 2001-2010. Jurnal Ilmiah Mahasiswa FEB, 1(1).

8. Cashin, P. 1995. Government spending, taxes, and economic growth. Staff Papers, 42(2), 237-269.

9. d'Agostino, G., Dunne, J. P., \& Pieroni, L. 2018. Military expenditure, endogeneity and economic growth. Defence and Peace Economics, 1-16.

10. Devarajan, S., Swaroop, V., \& Zou, H. F. (1996). The composition of public expenditure and economic growth. Journal of monetary economics, 37(2), 313-344.

11. Dhanang, P, S. 2013. Analisis Pengaruh Jumlah Penduduk, Jumlah Tenaga Kerja Dan Pendapatan Asli Daerah (Pad) Terhadap Pertumbuhan Ekonomi Di Kota Surakarta Tahun 1991-2011 (Doctoral dissertation, Universitas Muhammadiyah Surakarta).

12. Fahri Atahrim. 2013. Analisis Pengaruh Tenaga Kerja Dan Pengeluaran Pemerintah Terhadap Pertumbuhan Ekonomi Sektor Industri Kab/Kota Di Provinsi Jawa Tengah. Fakultas Ekonomi Dan Bisnis. Universitas Islam Negeri Syarif Hidayatullah. Jakarta 
13. Fan, S., Hazell, P., \& Thorat, S. 2000. Government spending, growth and poverty in rural India. American journal of agricultural economics, 82(4), 1038-1051.

14. Fölster, S., \& Henrekson, M. 2001. Growth effects of government expenditure and taxation in rich countries. European economic review, 45(8), 1501-1520.

15. Hein, E. 2018. Autonomous government expenditure growth, deficits, debt, and distribution in a neo-Kaleckian growth model. Journal of Post Keynesian Economics, 123.

16. Kuncoro, S. 2014. Analisis Pengaruh Pertumbuhan Ekonomi, Tingkat Pengangguran dan Pendidikan Terhadap Tingkat Kemiskinan di Provinsi Jawa Timur Tahun 2009-2011 (Doctoral dissertation, Universitas Muhammadiyah Surakarta).

17. Maharani, D. 2017. Analisis Pengaruh Investasi Dan Tenaga Kerja Terhadap Produk Domestik Regional Bruto (PDRB) Di Sumatera Utara. Intiqad: Jurnal Agama Dan Pendidikan Islam, 8(2).

18. Novianto, T. F., dan Atmanti, H. D. 2013. Analisis Pengaruh Pendapatan Asli Daerah, Investasi dan Angkatan Kerja Terhadap Pertumbuhan PDRB Provinsi Jawa Tengah Tahun 1992-2011 (Doctoral dissertation, Fakultas Ekonomika dan Bisnis).

19. Nurudeen, A., \& Usman, A. (2010). Government expenditure and economic growth in Nigeria, 1970-2008: A disaggregated analysis. Business and Economics Journal, 2010(4), 1-11.

20. Pamungkas, B. D., Kurniawansyah, K., dan Mustaram, R. A. 2018. Analisis Pengaruh Investasi Dan Tenaga Kerja Terhadap PDRB Kabupaten Sumbawa Tahun 2010-2016. JURNAL EKONOMI dan BISNIS, 14(3).

21. Ponzetto, G. A., \& Troiano, U. 2018. Social Capital, Government Expenditures and Growth (No. w24533). National Bureau of Economic Research.

22. Ratih, G. P. A., Utama, M. S., dan Yasa, I. N. M. 2017. Pengaruh Investasi, Pengeluaran Pemerintah, Tenaga Kerja Terhadap Produk Domestik Regional Bruto Dan Tingkat Kemiskinan Pada Wilayah Sarbagita Di Provinsi Bali. E-Jurnal Ekonomi dan Bisnis Universitas Udayana.

23. Sitaniapessy, H. A. 2013. Pengaruh pengeluaran pemerintah terhadap PDRB dan PAD. Jurnal Economia, 9(1), 38-51

24. Sulaksono, A. 2015. Analisis Produk Domestik Regional Bruto, Investasi, Tenaga Kerja Sektor Pertambangan Terhadap Tingkat Kemiskinan Di Indonesia. Universitas Gunadarma.

25. Umayi, D. 2017. Pengaruh Pengeluaran Pemerintah, Ekspor Dan Jumlah Penduduk Terhadap Pdrb Provinsi Di Indonesia Tahun 2011-2015 (Doctoral dissertation, University of Muhammadiyah Malang)

26. Weley, I. R., Kumenaung, A. G., dan Sumual, J. I. 2015. Analisis Pengaruh Inflasi dan Produk Domestik Regional Bruto (PDRB) terhadap Pendapatan Asli Daerah di Kota Manado. Jurnal Pembangunan dan Keuangan Daerah, 19(3).

27. Wibowo, W., Sinu, E. B., \& Setiawan. 2017. Gross regional domestic product estimation: Application of two-way unbalanced panel data models to economic growth in East Nusa Tenggara province. In AIP Conference Proceedings (Vol. 1825, No. 1, p. 020026). AIP Publishing.

28. Zahari. 2017. Pengaruh Pengeluaran Pemerintah Terhadap Pertumbuhan Ekonomi Di Provinsi Jambi. Jurnal of Economics and Business. Vol.1 No.1. 